\title{
Long-term patterns in dissolved organic carbon in boreal lakes: the role of incident radiation, precipitation, air temperature, southern oscillation and acid deposition
}

\author{
Jeff J. Hudson ${ }^{1}$, Peter J. Dillon ${ }^{1}$ and Keith M. Somers ${ }^{2}$ \\ ${ }^{1}$ Environmental and Resource Studies, Trent University, Dorset Environmental Science Centre, Box 39, Dorset, Ontario, POA 1E0, Canada \\ ${ }^{2}$ Ontario Ministry of the Environment, Dorset Environmental Sciences Centre, Box 39, Dorset, Ontario, POA 1E0, Canada \\ Email for corresponding author: jeff.hudson@usask.ca
}

\begin{abstract}
Both lake-specific (e.g. pH) and regional (e.g. precipitation) factors affect DOC concentration and pattern. Using annual DOC concentration in nine boreal lakes in the ice-free season, the potential influences of five regional factors, air temperature, precipitation, $\mathrm{SO}_{4}$ deposition, solar radiation (photosynthetically active radiation, or PAR) and the southern oscillation index (SOI) have been explored through multiple regression. Mean solar radiation, winter precipitation and summer precipitation explained $59 \%$ of the variation in the mean DOC concentration $\left(F_{3,17}=8.29, p=0.0013\right)$. Solar radiation and winter precipitation were correlated, negatively, while summer precipitation was correlated, positively, with DOC concentration. Because these relationships were based on only 21 years of data (1978 to 1998), the significance of the parameters in the regression model was evaluated with a randomisation test. This re-analysis indicated that summer precipitation did not contribute significantly to the regression model $\left(p_{\text {rand }}=0.183\right)$. The final multiple regression explained $50 \%$ of the variation in DOC $\left(F_{2,18}=9.33\right.$, $\left.p_{\text {rand }}=0.002\right)$ based on solar radiation and winter precipitation. These results suggest that solar radiation and winter precipitation have a significant role in determining long-term DOC concentration in boreal lakes.
\end{abstract}

Keywords: dissolved-organic-carbon, lakes, climate, solar-radiation, precipitation, acid-precipitation, Precambrian-Shield-Ontario

\section{Introduction}

Dissolved organic carbon (DOC) is an important complex of substances that affects numerous physical, chemical and biological processes in aquatic environments. For example, DOC binds many metals and nutrients (Francko, 1986; Mierle and Ingram, 1991), affects water transparency and thermal stratification (Perez-Fuentetaja et al., 2000; Snucins and Gun, 2000), affects $\mathrm{pH}$ and alkalinity (Oliver et al., 1983), is a substrate for microbial production (Tranvik, 1992; Wetzel et al., 1995) and most importantly, attenuates the penetration of harmful ultraviolet radiation (Scully and Lean, 1994; Morris et al., 1995).

Regional and global-scale anthropogenic stressors, including climate change, acid deposition and stratospheric ozone depletion, may all have negative effects on DOC concentration in freshwaters (Fig. 1). Increased ultraviolet radiation (UVR) will result in increased loss of DOC via photolysis (Molot and Dillon, 1997; Gennings et al., 2001).
Acidification of surface waters may increase the loss of DOC through accelerated photodecay processes (Dillon and Molot, 1997a; Schindler, 1998; Gennings et al., 2001; Anesio and Graneli, 2003), through chemical alterations caused by increases in metal concentration (Schindler et al., 1992), or through reduced fluxes of DOC from lake catchments (Schindler, 1998). In addition, climate change, predicted to increase summer temperatures and reduce soil moisture in eastern North America, may well increase lake water replenishment times and result in a more rapid loss of DOC (Dillon and Molot, 1997a; Curtis, 1998; Schindler, 1998).

The effect of local or system-specific factors on DOC, such as the proportion of wetland cover in the catchment (Eckhardt and Moore, 1990; Kortelainen, 1993; Dillon and Molot, 1997b), lake morphometry (Rasmussen et al., 1989; Kortelainen, 1993), or land use (Findlay et al., 2001), have received more attention than regional or global factors (e.g. 


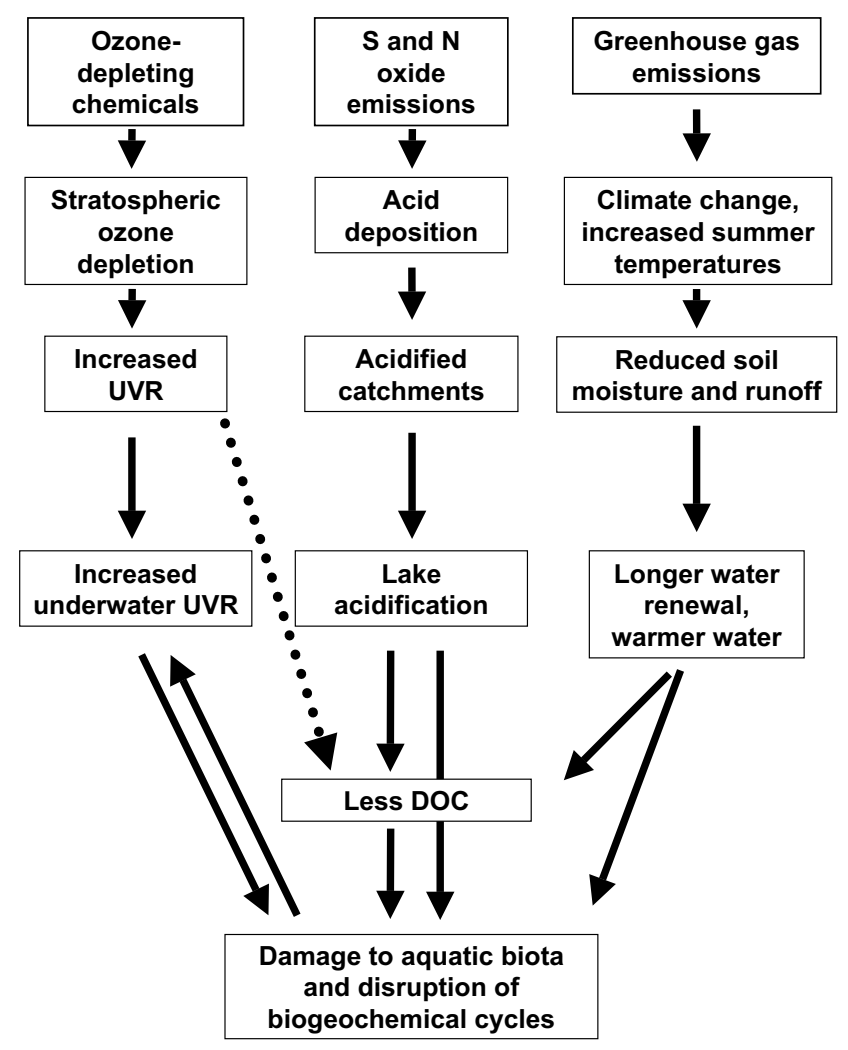

Fig. 1. Conceptual model of influence of anthropogenic emissions and ozone-depleting chemicals on DOC and ultimately on aquatic organisms in North Eastern North America. The dotted arrow depicts the DOC photodecomposition pathway driven by UVR.

climate and solar radiation). Notwithstanding documentation of interactions between precipitation and freshwater DOC (e.g. Urban et al., 1989; Hinton et al., 1997; Curtis, 1998; Schiff et al., 1998) and, in short-term studies, a negative interaction between DOC and solar radiation and lake acidity in aquatic systems (Graneli et al., 1996; Gao and Zepp, 1998; Gennings et al., 2001), the combined effects of climate, solar radiation and acid deposition on the long-term patterns of DOC have yet to be established. This information is essential to predict the long-term effects of anthropogenic stresses on aquatic systems (Gorham, 1996; Schindler, 2001).

The present exploratory study, therefore, sought evidence of an impact of climate parameters, solar radiation and acid deposition on long-term, multi-lake DOC patterns. The influence of lake-specific factors on DOC, not included here, have been examined elsewhere (Dillon and Molot, 1997b; Gennings et al., 2001). Whole-lake DOC concentrations were examined rather than just surface water DOC to obtain a more complete understanding of how whole-system DOC dynamics may be affected by climate, solar radiation and acid deposition trends.

\section{Methods}

DOC concentrations were measured in nine softwater oligotrophic lakes (Fig. 2) located in the boreal ecozone near the southern boundary of the Precambrian Shield (approximately $150 \mathrm{~km}$ north of Toronto, Ontario). The lakes have maximum depths of 6 to $38 \mathrm{~m}$ (Table 1), surface areas of 13 to 94 ha and water replenishment times of 1.1 to 7.7 years (Molot and Dillon, 1997; Dillon and Molot, 1997a). Whole-lake DOC concentrations were measured on 5 to 24 occasions per year during the ice-free period (Apr to Nov, 1978-98). All samples were collected at the deepest location in the lake either from the upper $5 \mathrm{~m}$ of the water column during the spring and fall overturns, or from the entire water column during the period of thermal stratification (June to October). Water was pumped from each stratum to the surface with a peristaltic pump. During thermal stratification, samples collected from each $2 \mathrm{~m}$ interval were volumeweighted according to the relative contribution of that $2 \mathrm{~m}$ stratum to each thermal layer (epi-, meta-, hypolimnion) of the lake and combined for chemical analysis. This approach yielded volume-weighted samples representative of each layer; the analytical results for the three layers were then
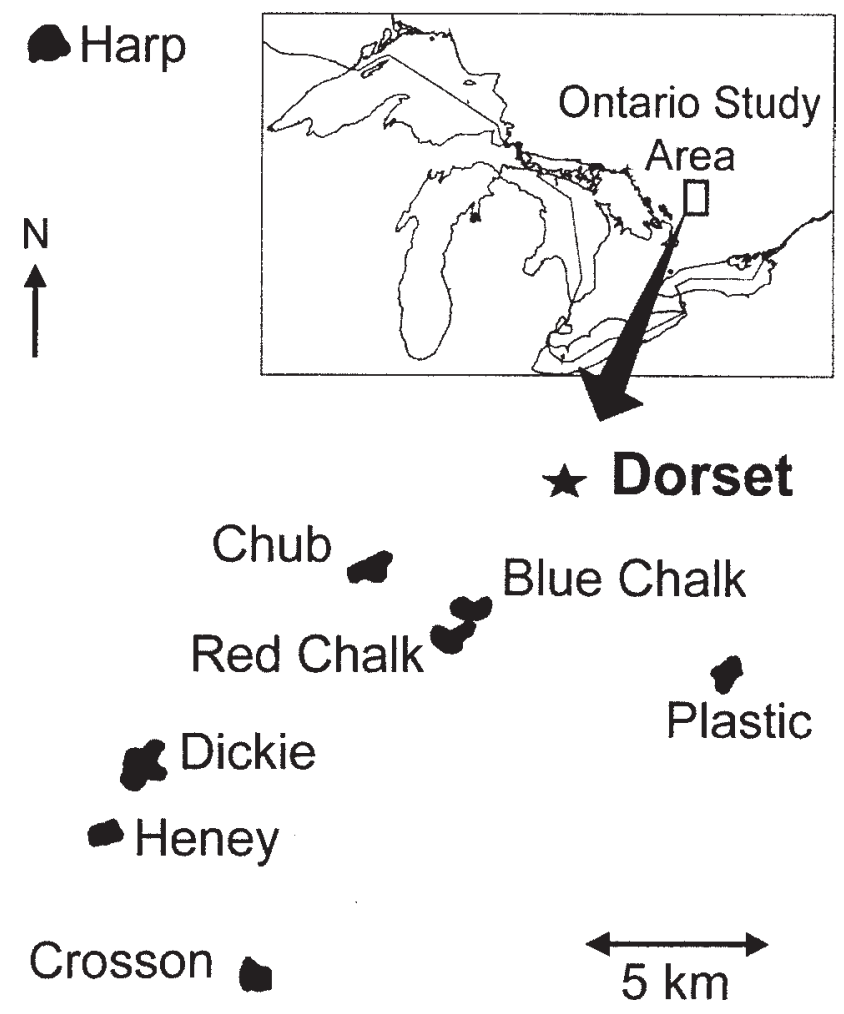

Fig. 2. Location of lakes studied near the town of Dorset (*), and in reference to South Central Ontario (inset). 
Table 1. Lake characteristics

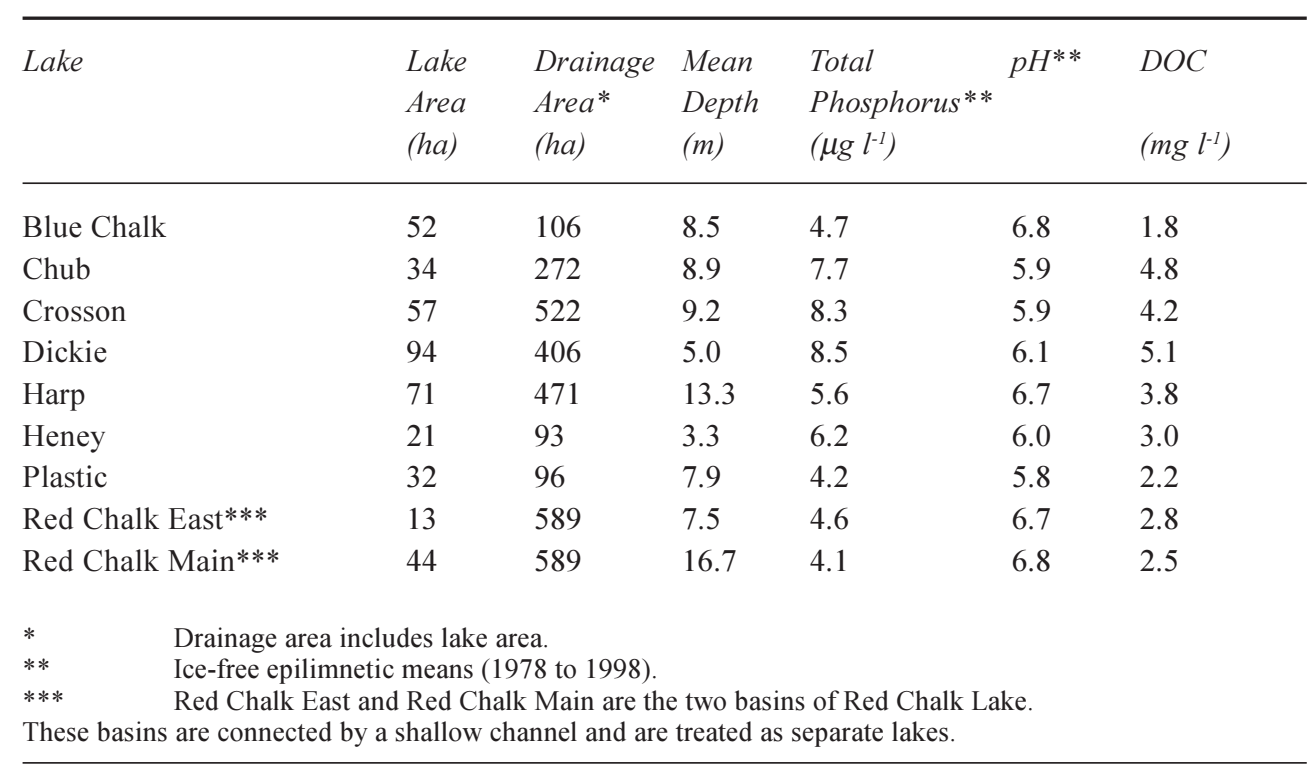

weighted according to the proportion of the whole lake volume that each thermal layer represented to give single, whole-lake, volume-weighted DOC measures for each sampling date. The mean DOC concentration of all the sampling dates for each ice-free season was then used in all subsequent analyses. DOC was measured by acidifying samples and flushing with nitrogen gas to remove inorganic C. Organic $\mathrm{C}$ was then oxidised to $\mathrm{CO}_{2}$ by exposure to UV radiation in acid persulfate media and measured, colorimetrically, with phenolphthalein using a Technicon auto analyser (Dillon and Molot, 1997a).

Precipitation, air temperature, $\mathrm{SO}_{4}$ deposition and photosynthetically active radiation (PAR) have been related to biogeochemical processes in these catchments (e.g. Schiff et al., 1998; Gennings et al., 2001; Dillon et al., 2003). Total precipitation, mean daily air temperature, and mean daily total PAR were measured at two nearby meteorological field stations (Locke and de Grosbois, 1986; Gennings et al., 2001). Measurements of $\mathrm{SO}_{4}$ deposition, described in detail in Dillon et al. (2003) were made on samples of bulk deposition collected in 4-8 continuously open, $0.25 \mathrm{~m}^{2}$, Teflon-coated collectors positioned in the catchments of the lakes studied and at the field laboratory. Deposition was estimated daily at each collector site and, because all deposition collectors (and lakes) lie within a $50 \mathrm{~km}$ radius, all data on any day were averaged to evaluate daily deposition. These values were summed to give monthly and annual deposition for the region. For several years, $\mathrm{SO}_{4}$ deposition was estimated separately at each site; however, there was no significant difference in annual depositions between sites.
An additional parameter, SOI, the standardised southern oscillation index, (NOAA, http://www.cpc.noaa.gov/data/ indices/soi), was included as another independent variable in the analyses. El Niño events can produce warm and dry conditions in north-eastern North America (especially during summer and autumn, Dillon et al., 1997). These events can be quantified using the SOI, which is a standardised measure of the concurrent differences in atmospheric pressure across the South Pacific Ocean. The occurrence of El Niño is indicated by a negative SOI value for several consecutive months. Changes in precipitation and temperature coincident with El Niño events are sufficient to affect biogeochemical cycles in the lakes studied (Dillon et al., 1997).

To correct for lake-specific differences in DOC concentrations, mean annual ice-free DOC concentrations for each lake were standardised to Z-scores by subtracting the 21-year mean and dividing by the standard deviation. The multi-lake ice-free mean DOC concentration (Z-score) was then calculated for each of the 21 years. These annual multi-lake ice-free means were used in all subsequent analyses (e.g. the multiple regression analysis). Each series of variables (i.e. SOI, temperature, precipitation, PAR and $\mathrm{SO}_{4}$ deposition) comprised a number of different summaries (e.g. quarterly, semi-annual and annual) listed in Table 2. The annual multi-lake ice-free mean DOC concentration was matched by year, or lagged by one year with these variables. Lagged forms of many variables were included to account for delayed responses in the dependent variable (multi-lake ice-free mean DOC concentration). For example, El Niño events may not affect a particular variable until half a year or more after their occurrence. Because there were more 
Table 2. Independent variable selection for multiple regression analyses with mean ice-free DOC concentration (Z-scored).

\begin{tabular}{|c|c|}
\hline Variables Considered & Form of Variable Analysed \\
\hline Total Precipitation (mm) & Quarterly, Dec-Mar ${ }^{\mathrm{a}}$, Mar-May, Ice-free period ${ }^{\mathrm{a}, \mathrm{b}}$, Calendar year $^{\mathrm{a}}$ \\
\hline Total $\mathrm{SO}_{4}$ Deposition & Quarterly, Dec-Mar ${ }^{\mathrm{a}}$, Ice-free period ${ }^{\mathrm{a}, \mathrm{b}}$, Calendar Year $^{\mathrm{a}}$ \\
\hline Mean Daily Temperature $\left({ }^{\circ} \mathrm{C}\right)$ & Quarterly, Dec-Mar ${ }^{\mathrm{a}}$, Ice-free period ${ }^{\mathrm{a}, \mathrm{b}}$, Calendar year ${ }^{\mathrm{a}}$ \\
\hline $\begin{array}{l}\text { Mean of the Daily Total of Photosynthetically } \\
\text { Active Radiation (PAR, } \mathrm{kJ} \mathrm{m}^{-2} \mathrm{day}^{-1} \text { ) }\end{array}$ & Quarterly, Dec-Mar ${ }^{\mathrm{a}}$, Ice-free period ${ }^{\mathrm{a}, \mathrm{b}}$, Calendar year ${ }^{\mathrm{a}}$ \\
\hline Mean Southern Oscillation Index (SOI) & $\begin{array}{l}\text { Quarterly, Mar-Novi, Apr-Sept }{ }^{\mathrm{a}} \text {, Dec-Feb, Ice-free period }{ }^{\mathrm{a}, \mathrm{b}}, \text { Calendar Year, } \\
\text { Canadian Hydrological Year }{ }^{\mathrm{a}, \mathrm{c}} \text {, United States Hydrological Year }{ }^{\mathrm{a}, \mathrm{c}}\end{array}$ \\
\hline \multicolumn{2}{|c|}{ 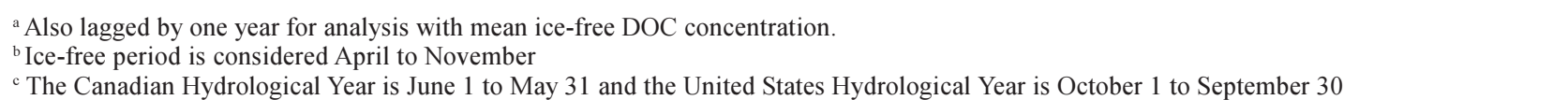 } \\
\hline
\end{tabular}

variables than observations ( $\mathrm{n}=21$ years), the exploratory analysis was undertaken in three steps. Initially, variables that were correlated $(p<0.1)$ with the mean DOC concentration were identified and retained for subsequent analyses. Separate multiple regression analyses were then run on these retained variables of each independent variable (i.e. precipitation, temperature, SOI, PAR, and $\mathrm{SO}_{4}$ deposition). The significant variables were then combined into a final analysis and the resultant multiple regression model was used to identify the most important variables. Only the significant variables of this last multiple regression analysis were used to describe the pattern in DOC concentration. A backward stepwise regression model confirmed the analysis. Because of the relatively small number of observations (i.e. 21 years), a randomisation test evaluated the significance of each parameter in the regression model (Manly, 1991). Randomisation-based $p$ values $\left(p_{\text {rand }}\right)$ were calculated from 10000 randomisations of the dependent variable ( DOC). A cautious approach was taken to rejection of variables (i.e. critical probability level set at 0.1 ) to avoid losing variables that might prove useful in the final analyses. Residuals met the parametric assumptions of the models (i.e. they were normally distributed and had homogeneous variance)

\section{Results and Discussion}

Mean ice-free DOC concentrations ranged from 1.8 to 5.2 $\mathrm{mg} \mathrm{L}^{-1}$ (Fig 3a). DOC concentrations were not available for Heney and Plastic Lakes in 1978 and for Red Chalk Lake East from 1980 to 1982. Although DOC patterns appeared to differ among lakes (Fig. 3a), when the data were standardised (Fig. 3b), a common pattern was evident: DOC concentrations were higher between 1978 and 1982 and from 1990 to 1997 (Fig. 3c). Variables describing the SOI and $\mathrm{SO}_{4}$ deposition were not correlated $(p<0.1)$ with the multilake average ice-free DOC pattern, unlike some summary variables for solar radiation (PAR), precipitation and temperature. The final multiple regression model including ice-free PAR (Apr to Nov), winter precipitation (Dec to Mar), and summer precipitation (July to Sept), accounted for $33.6 \%, 16.8 \%$ and $9.1 \%$ of the variation in DOC, respectively (Table 3 ). This multiple regression model was identical to a backward stepwise regression model that was used to confirm the initial result. Variance inflation factors and Durbin-Watson statistics indicated that multi-colinearity and autocorrelation, respectively, were not significant. However, a subsequent randomisation test indicated that summer precipitation explained only an insignificant amount of variation in DOC $\left(F_{1,17}=3.794, p_{\text {rand }}=0.183\right)$, so the model was reduced to the two predictors which accounted for a total of $50.3 \%$ of the variation in DOC (Table 3 ).

The pattern in ice-free PAR (Fig. 4a) may reflect the degree of cloud cover and aerosols in the atmosphere above the meteorological site; seasons with extensive cloud cover and greater concentrations of aerosols may have less incident PAR and UVR. Ice-free PAR was the variable most strongly correlated with the mean ice-free DOC concentration. In fact, the pattern in DOC is almost a mirror image of PAR (Fig. 4a); in turn, PAR is highly correlated with UVR (Gennings et al., 2001). Short-term studies have shown that both PAR and UVR are responsible for the photolytic breakdown of DOC (Mopper et al., 1991; Molot and Dillon, 1997; Gao and Zepp, 1998; Vahatalo et al., 2000). PAR has been emphasised because UVR measurements were not available for the full period of study. 


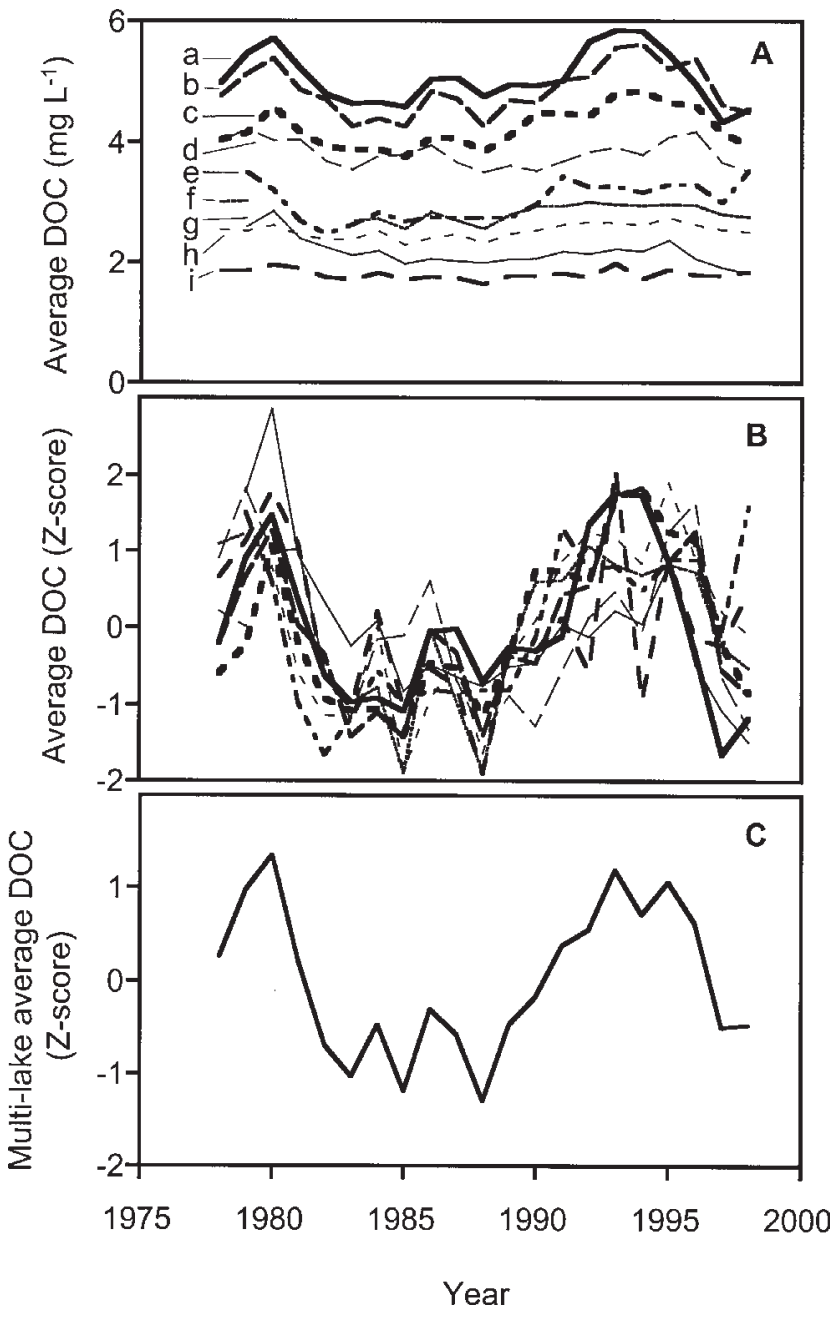

Fig. 3. Average DOC concentrations for the ice-free seasons from 1978 to 1998 for each of the nine study lakes (A). Standardised average DOC concentration for each lake $(B)$ and the common among lake pattern in average DOC concentration (C). Panels $A$ and B legend: a, Dickie Lake; b, Chub Lake; c, Crosson Lake; d, Harp Lake; e, Heney Lake; $f$, Red Chalk East; g, Plastic Lake; $h$, Red Chalk Lake main; i, Blue Chalk Lake.

The long-term significance of PAR and UVR on aquatic DOC is unknown, but may be estimated from short-term studies. Maximal rates of DOC photodecomposition to dissolved inorganic carbon (depicted by the dotted arrow in Fig. 1) are usually less than $1 \%$ day $^{-1}$. For example, rates of photodecomposition in Lake Straken (Sweden) were approximately $0.43 \%$ day $^{-1}$ when integrated over the mean lake depth of $4.1 \mathrm{~m}$ (Graneli et al., 1996). Although this rate appears small, it can be substantial over the water replenishment time of most lakes (Schindler, 1998). Even in lakes with short water replenishment times, the amount of DOC lost to photodecomposition processes can be considerable. Thus, using a mass balance approach,

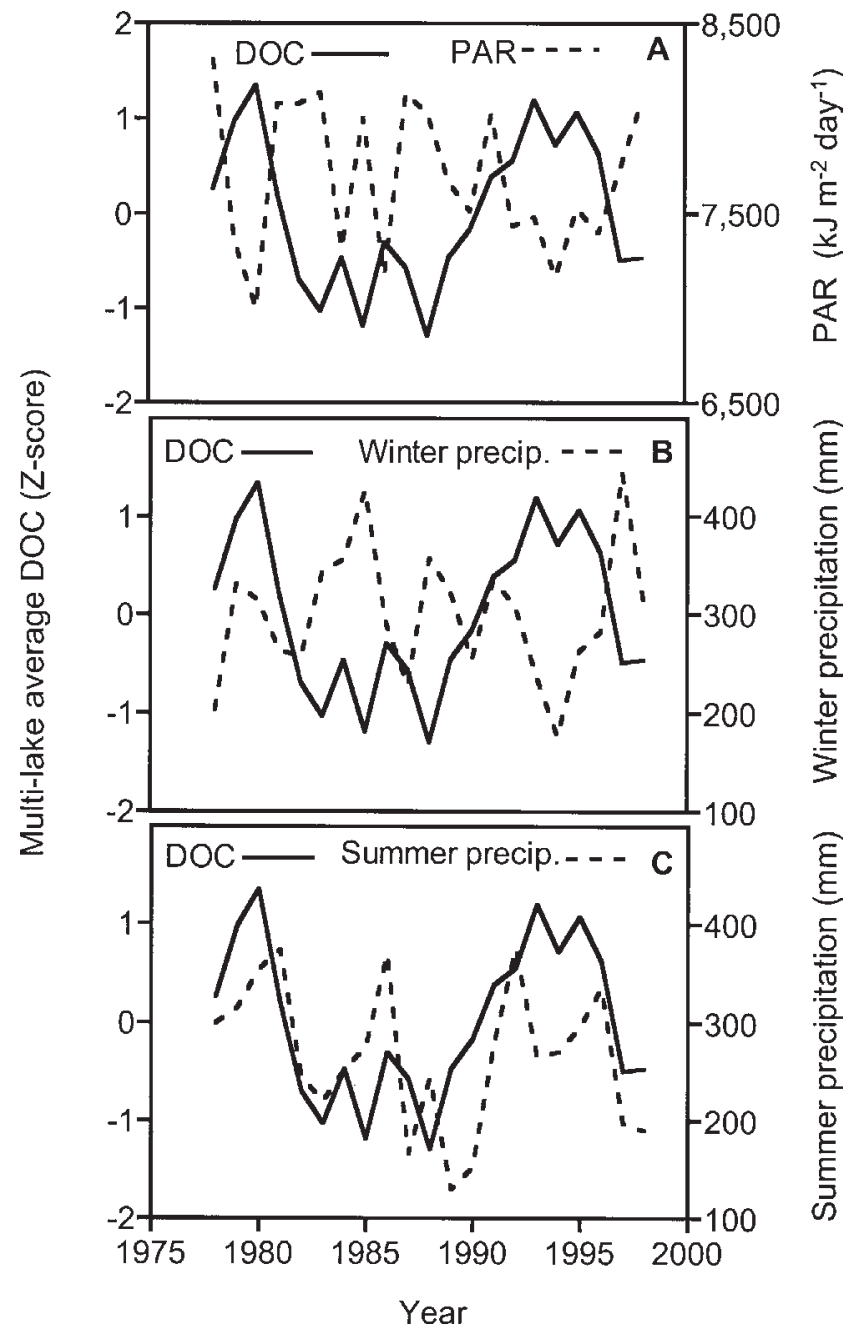

Fig. 4. Comparisons of standardized average DOC concentration for the ice-free season in all lakes as a function of year (1978 to 1998) with A) PAR (Apr to Nov), B) total winter precipitation (Dec to Mar), and C) total summer precipitation (July to Sept).

Andersen and Gjessing (2002) report that, during the summer and early fall, $33 \%$ of the organic matter in Lake Terjevann (Norway) was removed by photodecomposition processes. Additional losses of DOC, following exposure to solar radiation, may be mediated by microbial mineralisation of photoproducts, which are more susceptible to attack than the parent compounds (Bertilsson and Tranvik, 1998).

The long-term effect of solar radiation on DOC is also demonstrated in the literature on the Dorset lakes. In a mass balance study of 12 years of lake data, Molot and Dillon (1997) estimated that photodecomposition processes had the potential to remove most of the allocthonous DOC entering 
Table 3. A - multiple regression model $\left(\mathrm{n}=21, \mathrm{r}^{2}=0.59, F_{3,17}=8.29, p=0.001\right)$ predicting multi-lake average ice-free DOC (Z-score) from the mean daily ice-free total PAR (Apr to Nov, $\mathrm{kJ} \mathrm{m}^{-2}$ day $^{-1}$ ), total winter precipitation (Dec to Mar, mm), and total summer precipitation (July to Sept, $\mathrm{mm}$ ); and B - simplified regression model $\left(r^{2}=0.503, F_{2,18}=9.33, p_{\text {rand }}=0.002\right)$ after summer precipitation was removed ( $p_{\text {rand }}$ from 10000 randomisations).

\begin{tabular}{|c|c|c|c|c|c|}
\hline Parameter & Coefficient & t-statistic & $p$-value & $p_{\text {rand }}$ & $\begin{array}{l}\text { Partial } \\
\text { correlation }\left(r^{2}\right)\end{array}$ \\
\hline
\end{tabular}

\begin{tabular}{lcrlll}
\hline A - FuLL MODEL: & & & & & \\
Intercept & 7.32 & 2.58 & 0.020 & & \\
Mean ice-free PAR & $-8.94 \times 10^{-4}$ & -2.66 & 0.017 & 0.007 & 0.336 \\
Total winter precipitation & $-4.59 \times 10^{-3}$ & -2.47 & 0.024 & 0.064 & 0.168 \\
Total summer precipitation & $3.52 \times 10^{-3}$ & 1.95 & 0.068 & 0.183 & 0.091 \\
B - SIMPLIFIED MODEL: & & & & & \\
Intercept & 10.077 & 3.869 & 0.001 & & \\
Mean ice-free PAR & $-1.12 \times 10^{-3}$ & -3.342 & 0.004 & 0.005 & 0.336 \\
Total winter precipitation & $-4.91 \times 10^{-3}$ & -2.499 & 0.022 & 0.068 & 0.168 \\
\hline
\end{tabular}

the lakes. In a short-term study of photodecomposition of DOC in tributaries to the lakes, Gennings et al. (2001) found that $50 \%$ of stream DOC was lost in approximately 11 days under natural light conditions (Apr to Oct). In summary, solar radiation, through its role in DOC photodecomposition and other indirect pathways, has a significant negative longterm effect on DOC. This relationship is likely to strengthen, if incident UVR (and presumably high energy PAR) continues to increase as forecast (Taalas et al., 2000).

PAR and mean ice-free DOC (Z-scored) described above can be plotted against each other on logarithmic axes to examine the PAR-DOC relationship in more detail. The resultant equation for this relationship is:

$$
\log \text { DOC }(\text { Z-scored }+3.364)=-2.721 \log \text { PAR }+11.09
$$$$
\left(\mathrm{n}=21, \mathrm{r}^{2}=0.29, p=0.007\right) \text {, }
$$

where the value 3.364 is the grand mean DOC added to the Z-scored values to remove negatives for conversion to logarithms. The slope (-2.721) indicates that a slight increase in PAR results in a large decrease in DOC; such a relationship may result from the combination of direct (photodecomposition to dissolved inorganic carbon) and indirect effects of solar radiation on DOC. For example, solar radiation, by altering the structure of DOC, may make it more available for microbial breakdown (Wetzel et al., 1995; Bertilsson and Tranvik, 1998), or it may produce free radicals (e.g. hydrogen peroxide) that can attack and lead to further breakdown of DOC. Such processes are also accelerated under conditions of low $\mathrm{pH}$ (Gennings et al., 2001). The numerous effects of solar radiation on lake DOC are complex (particularly through indirect effects) and require additional study.
Winter precipitation was also correlated with the longterm DOC pattern (Fig. 4b). On the Precambrian Shield, winter precipitation accumulates as snow and melts and flushes through catchments rapidly in spring. At snowmelt, wetlands may have depleted pools of labile DOC retained from previous autumn rain events (Hinton et al., 1997, 1998; Schiff et al., 1998); alternatively, labile DOC may have been frozen and not flushed from the wetlands, or both scenarios may be combined. Consequently, the high volume of water and low concentrations of DOC in streams during spring snowmelt (Mierle and Ingram, 1991; Schiff et al., 1998) may have diluted the existing concentration of DOC in these lakes, resulting in the negative relationship between icefree DOC and winter precipitation (Fig. 4b). To address this hypothesis, the monthly records of DOC load and DOC concentration in streams entering three of the lakes (Fig. 5), for which adequate information was available, have been examined. As predicted, the concentration of DOC in the stream water in spring was at a yearly minimum, even though loading of DOC was maximal. Therefore, spring snowmelt may have diluted the existing DOC concentration in the lakes.

Another compatible, but more complex explanation of the negative relationship between winter precipitation and icefree DOC, is that an increase in winter precipitation, resulting in substantial runoff in spring may displace a large proportion of a lake's volume downstream. The old DOC, left in the lake from previous seasons, may be replaced by more labile DOC from the catchment that may photodecompose rapidly and cause a greater decline in lake DOC than would occur in years with lower winter precipitation. Although DOC data prior to snowmelt are not available for the lakes in the present study, this explanation 


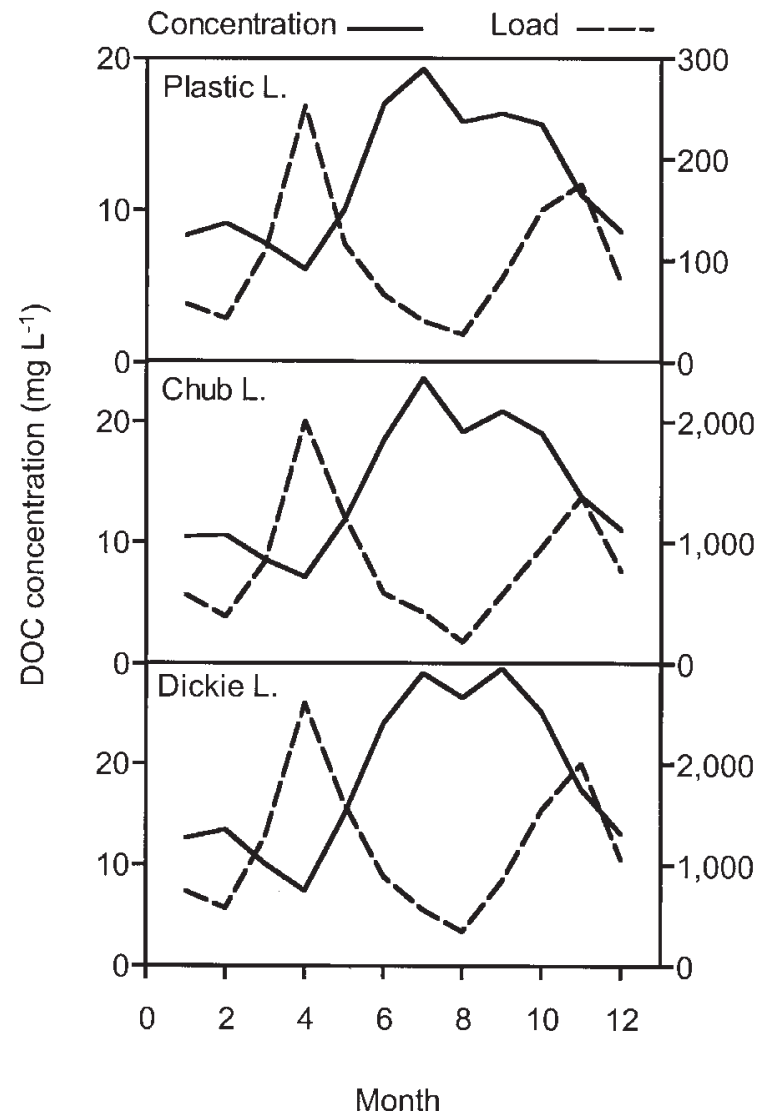

Fig. 5. Mean monthly DOC load $(\mathrm{kg})$ and concentration $\left(m g \mathrm{~L}^{-1}\right)$ entering three of the study lakes (1978 to 1997). Note the inverse relationship between DOC load and DOC concentration in each lake. Maximal loads and minimal concentrations of DOC are found in spring. Low spring DOC concentrations in streams may dilute existing lake DOC concentrations.

may be tested by examining in-lake DOC concentrations and DOC lability just before and just after snowmelt. Both explanations described above are not mutually exclusive; they may act together in affecting DOC concentration.

Summers with high rainfall were associated with increases in DOC concentration (Fig 4c). Summer rainstorms can increase stream DOC concentrations greatly (Easthouse et al., 1992; Hinton et al., 1997), particularly after dry periods when the upper layers of peat have been oxidised to produce labile DOC (Dillon and Molot, 1997b; Bertilsson and Tranvik, 1998; Freeman et al., 2001). This labile DOC, flushed from wetlands during high flows, can increase lake concentrations. However, summer precipitation explained only $9 \%(p=0.068)$ of the DOC variance after considering the effect of solar radiation and winter precipitation (combined variance explained 50\%). Hence, summer precipitation was dropped from the model in subsequent randomisation procedures ( $p=0.186$, Table 3$)$. Lakes with more rapid water replenishment times (i.e. $<1$ year) may be affected more by summer rainfall than those in the present study where water replenishment times exceed one year. In summary, the results indicate that the influence of precipitation on DOC concentration is a function not only of the quantity of precipitation (Urban et al., 1989) but also of the season when it occurs (winter or summer). For instance, a year with more precipitation in winter (snow) and less in summer would likely result in reduced DOC concentrations in these lakes.

SOI variables were not correlated with the multi-lake average ice-free DOC. Other water chemistry variables, particularly those directly related to acid deposition, have been correlated with the frequency of El Niño events (Dillon et al., 1997). El Niño (and La Niña) events affect catchments through changes in precipitation, temperature and incident radiation. Consequently, these latter variables are linked more directly to the catchment than the SOI and, therefore, are more likely to be correlated with the DOC concentrations.

A similar outcome was reported when the effect of the North Atlantic Oscillation was compared with that of more local climate conditions on a Swedish lake (Blenckner and Chen, 2003).

The lakes now being studied are sensitive to acidification (Dillon et al., 1978). The photodecomposition of DOC entering them is accelerated by low values of $\mathrm{pH}$ (Gennings et al., 2000). Therefore, annual and seasonal differences in acid deposition (measured as $\mathrm{SO}_{4}$ ) in the catchments may increase lake acidity and cause reductions in lake DOC concentrations. However, analyses revealed that the acid deposition variables were not correlated with the multi-lake average ice-free DOC. Interestingly, the rate of recovery of the lakes from acid conditions is complex. Ultimately, $\mathrm{SO}_{4}$ deposition rates affect lake acidity but global scale climate indices, the SOI and the North Atlantic Oscillation index influence, strongly, the timing and quantity of $\mathrm{SO}_{4}$ entering the lakes (Dillon et al., 2003; Dillon et al., 1997). No relationship between the SOI and the multi-lake average ice-free DOC pattern was found. Consequently, seasonal or annual $\mathrm{SO}_{4}$ deposition rates are unlikely to affect the multilake average ice-free DOC.

While Freeman et al. (2002) reported a strong positive correlation between DOC export and air temperature, only weak negative correlations $(0.05<\mathrm{p}<0.1)$ were found in the present study between temperature and the multi-lake average ice-free DOC. However, negative temperature effects (climate warming) on the DOC of boreal lakes have been reported elsewhere (Schindler, 1997; Curtis, 1998). The different responses between studies may reflect the large differences in the environments under which they were conducted, most notably in climate, vegetation cover, age 
of peat and underlying soil type. Furthermore, the type and form of variables used in different analyses may also lead to different conclusions. For example, the present study may be unique for its inclusion of solar radiation variables. Although temperature was found to be so weakly correlated with DOC that it was removed early in the analyses, temperature may be an important indirect factor in boreal catchments by affecting water replenishment rates in lakes (Schindler, 1997).

The simpler model (B) and the full model (A) explain $50 \%$ and $60 \%$, respectively, of the variance in the mean ice-free DOC pattern (Table 3). Although not analysed here and beyond the scope of this study, the remaining variance may be attributable to local variables, particularly to the extent of wetlands in the catchments. For example, the proportion of the catchment covered by peat lands accounted for much of the variance in a model of long-term average DOC export from the catchments (Dillon and Molot, 1997b). However, soil conditions (Dillon and Molot, 1997b; Schiff et al., 1998), catchment slope (i.e. upland and lowland DOC), lake morphometry (Rasmussen et al., 1989; Schiff et al., 1998), water renewal rates (Curtis, 1998) and other local variables may affect the long-term pattern in DOC in the lakes under study.

The present results indicate clearly that incident radiation and climate (precipitation) have a profound long-term effect on DOC concentrations in boreal lakes. Slight changes to incident radiation and precipitation will alter physical, chemical and biological processes in aquatic environments. Additional factors, such as lake acidification, e.g. from $\mathrm{SO}_{\mathrm{x}}$ and $\mathrm{NO}_{\mathrm{x}}$ emissions (Dillon and Molot, 1997a; Gennings et al., 2001) and climate warming, affect DOC concentrations in lakes (Curtis, 1998; Schindler, 1998). Isolating the combined effects of these anthropogenic stressors on different freshwater ecosystems poses a formidable task for future studies. An additional future challenge will be the integration of both lake-specific and regional factors into comprehensive predictive models.

\section{Acknowledgements}

This work was supported financially by grants to P.J.D. and J.J.H. from N.S.E.R.C. (Canada) and from an Ontario Power Generation Inc. grant to P.J.D. Many thanks are due to B. Clark, J. Findeis, B. Girard, R. Reid, L. Scott, P. Sutey, and D. Evans for technical assistance and to the Dorset Environmental Sciences Centre (Ministry of the Environment, Ontario) for logistical support. The authors are grateful to W. D. Taylor, L. Molot, M. Turner and J. Sheard for helpful comments on the original manuscript.

\section{References}

Andersen, D.O. and Gjessing, E.T., 2002. Natural organic matter (NOM) in a limed lake and its tributaries. Water Res., 36, 23722382.

Anesio, A.M. and Graneli, W., 2003. Increased photoreactivity of DOC by acidification: implications for the carbon cycle in humic lakes. Limnol. Oceanogr., 48, 735-744.

Bertilsson, S. and Tranvik, L.J., 1998. Photochemically produced carboxylic acids as substrates for freshwater bacterioplankton. Limnol. Oceanogr., 43, 885-895.

Blenckner, T. and Chen, D.L., 2003. Comparison of the impact of regional and North Atlantic atmospheric circulation on an aquatic ecosystem. Climate Res., 23, 131-136.

Curtis, P.J., 1998. Climatic and Hydrologic control of DOM concentration and quality in lakes. In: Ecological Studies, T. Hessen (Ed.) Volume 133. Springer. 93-105

Dillon, P.J. and Molot, M.L., 1997a. Dissolved organic and inorganic carbon mass balance in central Ontario Lakes. Biogeochemistry, 36, 29-42.

Dillon, P.J. and Molot, M.L., 1997b. Effect of landscape form on export of dissolved organic carbon, iron, and phosphorus from forested stream catchments. Water Resour. Res., 33, 2591-2600.

Dillon, P.J., Jeffries, D.S., Snyder, W., Reid, R., Yan, N.D., Evans, D., Moss, J. and Scheider, W.A., 1978. Acidic precipitation in south-central Ontario: recent observations. J. Fish. Res. Board Can., 35, 809-815.

Dillon, P.J., Molot, M.L. and Futter, M., 1997. The effect of El Nino-related drought on recovery of acidified lakes. Environ. Monit. Assess., 46, 105-111.

Dillon, P.J., Somers, K.M., Findeis, J. and Eimers, M.C., 2003. Coherent responses of lakes in Ontario, Canada to reductions in sulphur deposition: the effects of climate on recovery. Hydrol. Earth Syst. Sci. In press.

Easthouse, K.B., Mulder, J., Christophersen, N. and Seip, H.M., 1992. Dissolved organic carbon fractions in soil and stream water during variable hydrological conditions at Birkenes, Southern Norway. Water Resour. Res., 28, 585-1596.

Eckhardt, B.W. and Moore, T.R, 1990. Controls on dissolved organic carbon concentrations in streams, southern Quebec. Can. J. Fish. Aquat. Sci., 47, 1537-1544.

Findlay, S., Quinn, J.M., Hickey, C.W., Burrell, G. and Downes, M., 2001. Effects of land use and riparian flowpath on delivery of dissolved organic carbon to streams. Limnol Oceanogr., 46, 345-355.

Francko, D.A., 1986. Epilimnetic phosphorus cycling: influence of humic materials and iron on coexisting major mechanisms. Can. J. Fish. Aquat. Sci.. 43, 302-310.

Freeman, C., Evans, C.D., Monteith, D.T., Reynolds, B. and Fenner, N., 2001. Export of organic carbon from peat soils. Nature, 412, 785

Gao, H. and Zepp, R.G., 1998. Factors influencing photoreactions of dissolved organic matter in a coastal river of the southeastern United States. Environ. Sci. Technol., 32, 2940-2946.

Gennings, C., Molot, L.A. and Dillon, P.J., 2001. Enhanced photochemical loss of organic carbon in acidic waters. Biogeochemistry, 52, 339-354.

Gorham, E., 1996. Lakes under a three-pronged attack. Nature, 381, 109-110.

Graneli, W., Lindell, M. and Tranvik, L.J., 1996. Photo-oxidative production of dissolved inorganic carbon in lakes of different humic content. Limnol. Oceanogr., 41, 698-706.

Hinton, M.J., Schiff, S.L. and English, M.C., 1997. The significance of storms for the concentration and export of dissolved organic carbon from two Precambrian Shield catchments. Biogeochemistry, 36, 67-88. 
Hinton, M.J., Schiff, S.L. and English, M.C., 1998. Sources and flowpaths of dissolved organic carbon during storms in two forested watersheds of the Precambrian Shield. Biogeochemistry, 41, 175-197.

Kortelainen, P., 1993. Content of total organic carbon in Finnish lakes and its relationship to catchment characteristics. Can. J. Fish. Aquat. Sci., 50, 1477-1483.

Locke, B.A. and de Grosbois, E., 1986. Meteorological database for the Muskoka/Haliburton Area, Ontario. Min. Environ. Data Report DR 86/5 ed. Queen's Printer for Ontario.

Manly, B.F.J., 1991. Randomization and Monte Carlo methods in biology. Chapman and Hall, London, UK

Mierle, G. and Ingram, R., 1991. The role of humic substances in the mobilization of mercury from watersheds. Water Air Soil Pollut., 56, 349-357.

Molot, L.A. and Dillon, P.J., 1997. Photolytic regulation of dissolved organic carbon in northern lakes. Global Biogeochem. Cycle, 11, 357-365.

Mopper, K., Zhou, X., Kieber, R.J., Kieber, D.J., Sikorski, R.J. and Jones, R.D., 1991. Photochemical degradation of dissolved organic carbon and its impact on the oceanic carbon cycle. Nature, 353, 60-62.

Morris, D.P., Zagarese, H., Williamson, C.E., Balseiro, E.G., Hargreaves, B.R., Modenutti, B., Moeller, R. and Queimalinos, C., 1995. The attenuation of solar UV radiation in lakes and the role of dissolved organic carbon. Limnol. Oceanogr., 40, 13811391.

Oliver, B.G., Thurman, E.M. and Malcolm, R.L., 1983. The contribution of humic substances to the acidity of colored natural waters. Geochim. Cosmochim. Acta, 47, 2031-2035.

Perez-Fuentetaja, A., Dillon, P. J., Yan, N. D. and McQueen, D. J., 1999. Significance of dissolved organic carbon in the prediction of thermocline depth in small Canadian Shield lakes. Aquat. Ecol., 33, 127-133.

Rasmussen, J.B., Godbout, L. and Schallenberg, M., 1989. The humic content of lake water and its relationship to watershed and lake morphometry. Limnol. Oceanogr., 34, 1336-1343.

Schiff, S., Aravena, R., Mewhinney, E., Elgood, R., Warner, B., Dillon, P. and Trumbore, S., 1998. Precambrian shield wetlands: hydrologic control of the sources and export of dissolved organic matter. Climatic Change, 40, 167-188.
Schindler, D.W., 1997. Widespread effects of climatic warming on freshwater ecosystems in North America. Hydrol. Process., 11, 1043-1067.

Schindler, D.W., 1998. A dim future for boreal waters and landscapes: cumulative effects of climatic warming, stratospheric ozone depletion, acid precipitation, and other human activities. Bioscience, 48, 157-164.

Schindler, D. W., 2001. The cumulative effects of climate warming and other human stresses on Canadian freshwaters in the new millennium. Can. J. Fish. Aquat. Sci., 58, 18-29.

Schindler, D.W., Bayley, S.E., Curtis, P.J., Parker, B.R., Stainton, M.P. and Kelly, C.A., 1992. Natural and man-caused factors affecting the abundance and cycling of dissolved organic substances in Precambrian Shield lakes. Hydrobiologia, 229, $1-21$.

Scully, N.M. and Lean, D.R.S., 1994. The attenuation of ultraviolet radiation in temperate lakes. Adv. Limnol., 45, 135-144.

Snucins, E. and Gunn, J., 2000. Interannual variation in the thermal structure of clear and colored lakes. Limnol. Oceanogr., 45, 1647-1654.

Taalas, P., Kaurols, J., Kylling, A., Shindell, D., Sausen, R., Dameris, M., Grewe, V. and Herman, J., 2000. The impact of greenhouse gases and halogenated species on future solar radiation doses. Geophys. Res. Let., 27, 1127-1130.

Tranvik, L.J., 1992. Allochthonous dissolved organic matter as an energy source for pelagic bacteria and the concept of the microbial loop. Hydrobiologia, 229, 107-114.

Urban, N.R., Bayley, S.E. and Eisenreich, S.J., 1989. Export of dissolved organic carbon and acidity from peatlands. Water Resour. Res., 25, 1619-1628.

Vahatalo, A.V., Salkinoja-Salonen, M., Taalas, P. and Salonen, K., 2000. Spectrum of the quantum yield for photochemical mineralization of dissolved carbon in a humic lake. Limnol. Oceanogr., 45, 664-676.

Wetzel, R.G., Hatcher, P.G. and Bianchi, T.S., 1995. Natural photolysis by ultraviolet irradiance of recalcitrant dissolved organic matter to simple substrates for rapid bacterial metabolism. Limnol. Oceanogr., 40, 1369-1380. 